\title{
A model of collaborative innovation between local government and tourism operators
}

\author{
C. Pons-Morera ${ }^{1}$ (D) L. Canós-Darós ${ }^{2}$. \\ I. Gil-Pechuan ${ }^{3}$
}

\begin{abstract}
This research proposes a framework for collaborative innovation in a public private partnership by applying techniques that combine quantitative data collection and qualitative depth. It proposes a collaborative model that looks to provide competitive advantage by improving tourist services from two perspectives: from the core of public administration, and from the private tourist sector perspective.
\end{abstract}

Keywords Collaborative innovation - Concept mapping - Public administration Public private partnership · Technological services · Tourism

\section{Introduction}

There is renewed interest in the concept of public-private partnerships both in Europe and the US, though the performance of this type of collaboration is coming under scrutiny (Hodge and Greve 2017). In line with the findings of Porter (1990),

C. Pons-Morera

carponmo@upvnet.upv.es

L. Canós-Darós

loucada@omp.upv.es

I. Gil-Pechuan

igil@doe.upv.es

1 IGIC, Business Organization Department, Polytechnic University of Valencia, Camí de Vera s/n. 46022, Valencia, Spain

2 ROGLE, Business Organization Department, Polytechnic University of Valencia, Camí de Vera s/n. 46022, Valencia, Spain

3 EBIM, Business Organization Department, Polytechnic University of Valencia, Camí de Vera s/n. 46022, Valencia, Spain 
the government's role should be to act as a catalyst by stimulating and encouraging companies to increase their aspirations and levels of competitiveness by supporting the creation of specialized, previously identified factors, as reflected in the Rooter report (2010). While the competitive advantage conferred by innovation in its different forms has become apparent for companies in any sector in a global context, innovation in services is often regarded as the first choice due to its relative economic accessibility. Advanced countries, and some developing ones, can make innovation in services their growth path.

This differentiation requirement is apparent in the Spanish Tourism Plan Horizon (2020); the tourist sector must meet new market needs and anticipate them in order to detect and seize upon opportunities by listening to customers to provide them with new products and services. There is a pressing need for the sector to adapt tourism business services at the pace required by market trends, which requires increasingly specialized municipal services, and in-depth research to attempt to identify resorts that will improve the quality of the tourist offer in order for the industry to remain sustainable (Bruntland 1987).

The choice of Spain to study public private partnerships for tourism development is clearly justified by the national statistics on world tourism. As shown by United Nations World Tourism Organization data (UNWTO 2015), in 2014, Spain was the country to welcome the third largest number of international tourists, with 65 million visitors (after France and the USA) and was the second country in the world (after the USA) with income from international tourism, and first in Europe, with income reaching 62.6 thousand million US dollars. Tourism in Spain represented 16.0\% of GDP in 2015 (World Travel and Economic Impact 2016). At this juncture, the strategic sectors of the domestic economy should act as levers or catalysts to promote a change of scene that puts us further along the path of growth and employment generation. The inclusion of tourism as one of those levers must be a priority challenge due to its cross-sectional nature, for its economic driving force, and for its orientation towards markets that show the first signs of economic recovery (National and Integral Tourism Plan 20122015).

In the present case, we identify a collaboration model between local government and tourism operators from the perspective of both municipal management experts and business management experts in the tourist sector. The paper is divided into seven sections. A review of the literature is followed by a description of the methodology in which we lay down the criteria for using concept mapping and cluster analysis in order to attain the research objectives and describes the progression through the seven steps of the method. Sections 4 and 5 give detailed descriptions and analysis of the two groups surveyed from the point of view of public administration and the private sector. An analysis of this case allows us to build a collaborative model between local government and tourism entrepreneurs that intend to go some way to bridging the gap in collaboration between these two agents via a model that is presented in Sect. 6. The last section contains the conclusions that can be drawn from results and highlights the limitations of the research. 


\section{Literature review}

The improvement of services offered by public administrations in general affects tourism management and is, therefore, an issue that has led to numerous studies on the optimization of resources. Examples of such analyses include a sports facility public body (Rodríguez et al. 2010), the proposal of a multidimensional model to measure the trust that a tourist destination holds based on its institutions (Marinao and Chasco 2012); or monitoring the financial condition of municipalities of Galicia (Buch and Cabaleiro 2011). Other examples of the effects of public administration policies on tourism include an e-book lending library (Clavero et al. 2009) or, with regard to the closeness of local government to the citizen perspective, E-Government is currently one of the issues of concern for experts, and it has been studied to monitor the stages of its implementation (Muñoz-Cañavate and Chaín Navarro 2004), and also for its quality and performance (Soler-López 2013). León and Zapico (2003) indicate that the goal of e-Government is to illustrate in practice how citizens and businesses can reap benefits from online public services in their everyday needs and the carrying out of non-face-to-face administrative tasks from an online platform (Bustelo and García-Morales 2008).

Tourism-based collaborative innovation has given way to several studies, which focus on a variety of aspects, such as making effective use of the opinions of virtual communities of users on tourist services in order to innovate (improve) these services (Baglieri and Consoli 2009), or as an opportunity for less developed countries, e.g., Gambia and Tanzania, to differentiate their tourist products by making them more competitive (Carlisle et al. 2013) by promoting an area to encourage innovation and the business spirit where the importance of institutional support is also shown by encouraging the creation of networks, knowledge transfer and better practices. Along these lines, Nunkoo (2015) presents a study about the Niagara region in Canada, which confirms that suitable tourist development has a determining impact on political trust. Klodiana et al. (2012) identify the necessary optimization of resources that promote tourism used by local government, and the role of institutions in forging a sustainable model. The collaboration needed to produce sustainable models has been examined in several studies, although it has been limited in some cases by the government's interventionism, as stressed by Wang and Honggang (2014), since high interventionism diminishes the performance of the tourist companies that depend on natural resources.

Collaboration between public and private sectors, (PPP), stands out as a strategic tool for tourist development, where the fragmented tourist offer, combined with the need for overall tourist products that satisfy customers, favors cooperation in tourist regions. The reason for reaching this type of agreement and the nature of such associations has been widely acknowledged, for example in the work of Selin and Chavez (1994, 1995). These authors define it as a collaboration with a purpose shared by both agents, who would otherwise be independent.

After several studies into collaborative innovation or PPP in tourism, Queiroz and Rastrollo-Horrillo (2015) state that there are five theories that justify the decision to collaborate in tourism: (1) the Resource Dependence Theory (Pfeffer 
and Salancik 1978), where stakeholders possess important resources through which they are able to control other types of resources (Greenwood 1993; Wang and Fesenmaier 2007; Nordin and Svensson 2007); (2) the Transaction Cost Theory (Williamson 1975), which justifies collaboration to reduce the costs of information and negotiation to acquire competitive advantages (Beritelli et al. 2007; Wang and Fesenmaier 2007; Wang 2008); (3) the Strategic Management Theory (Porter, 1990; Prahalad and Hamel 1990) by applying the creation of a complete tourist product that offers an all-round tourist experience, which is achieved by the complementarity of agents (Pechlaner and Tschurtschenthaler 2003; Wang and Fesenmaier 2007; Czernek 2013); (4) the Network Theory (Freeman and McVea 1984; Granovetter 1985; Wood and Gray 1991; Gulati 1995) which states that relations among agents are promoted by recognition, mutual acceptance and seeking common interests; (5) the life cycle theory (Czernek 2013; Santos et al. 2014) which identifies endogenous factors that can determine competitiveness in view of the entry of new competitor tourist destinations.

It can thus be concluded that innovative collaboration between public administrations and private companies that manage tourist products (PPP) has resulted in numerous research cases, and that an increasing number of researchers (Caffyn and Jobbins 2003; Velasco 2007; Dinica 2009; Beaumont and Dredge 2010; Dredge and Whitford 2011; Moscardo 2011; Hultman and Hall 2012) defend the greater participation of residents and other stakeholders in sustainable local tourism development, defined by the UNWTO (2005) as "Tourism that takes full account of its current and future economic, social and environmental impacts, addressing the needs of visitors, the industry, the environment and host communities."

In light of the importance of Spanish tourism on a national and European scale, we focus on the efforts of one town to develop a public private partnership model that can be replicated in other contexts as a driver of the development of services than can enhance the possibility of local development in tourism. The town of Oliva is located on Spaińs south-east Mediterranean coast. It has $11.8 \mathrm{~km}$ of sandy beaches, awarded the distinctive Blue Flag (European Directive 2006/7/EC) that acknowledges the pure quality of the sea, accessibility and respect for the environment, granted by the Foundation for Environmental Quality of the European Union (2014), which, along with its proportion of coastline, makes it one of the top tourist beach destinations in Spain.

\section{Methodology}

We use concept mapping and cluster analysis to identify an intelligent use of resources to improve the competitiveness of tourism businesses, based on previous studies in which a tourist city is identified as a tourist cluster, such as Benidorm (Miret-Pastor and Segarra-Oña 2011), or the case study on tourism in the region of Valencia (Miret-Pastor et al. 2009). The concept mapping approach aims to combine the resources available with the capabilities of stakeholders to develop and to improve a tourist town for it to become sustainable (Bruntland 1987), where 
additional resources are provided by optimal tourism management for it to finally be considered a tourism cluster with its consequent economic importance.

We can define concept mapping as a graphical representation that combines qualitative and quantitative information, which reflects the result of group thinking, highlighting clusters of ideas by their similarity or closeness and their relevant importance (Burke et al. 2005). Concept mapping (Trochim and Linton 1986) structures the conceptualization process in such a way that the ideas expressed in group dynamics end up on a perceptual map, which allows us to see how the ideas relate to one another and, optionally, establish which ideas are the most important, relevant, or appropriate. Trochim (1989) later refines the definition and confers greater prominence to the graphical representation of a groupthink.

Following Trochim (1989), the six steps shown in Fig. 1 form the basis of concept mapping.

Step 1: Preparing the study. The project objective is identified, as are the profile and number of participants.

Step 2: Generating ideas by means of the brainstorming technique and promoting social interaction and exchanging ideas (Khattri and Miles 1994).

Step 3: Structuring ideas. Cards with the ideas obtained from the previous step are handed out to each subject to be classified on a Likert-type scale with values from 1 to 5 (Barbero 2009). They should be grouped according to closeness or similarity.

Step 4: Analyzing data. This step is divided into three stages: (a) the location of each statement is analyzed using the combined dissimilarity matrix, which undergoes a two-dimension multidimensional scaling to determine the distance among them; (b) a conglomerate analysis (Anderberg 1973; Everitt 1980) is done using Ward's algorithm because it is that which provided better interpretation results than other approaches; (c) the final analysis consists in reflecting the average classification of each proposed idea and each cluster.

Step 5: Interpreting plans. The group of experts is provided with the mapping concept obtained in the previous point to assess the results and to allocate a denomination to each cluster.

Step 6: Using maps. At this point, maps are taken as a graphical representation of the explanation provided by the group of experts about a specific concept, and are a theoretical representation of the experts' opinions of the theme.

\section{Capacity diagnosis for technological improvement according to public administration experts}

The first contacts were made at the highest level of local authority with a view to obtaining authorization, agree on the methodology to be used, and verify the local authority's commitment with the content and objective pursued, bearing in mind its experience and interest in determining how administration can influence tourism and optimize resources. At the start of 2012, we arranged a meeting with fourteen 


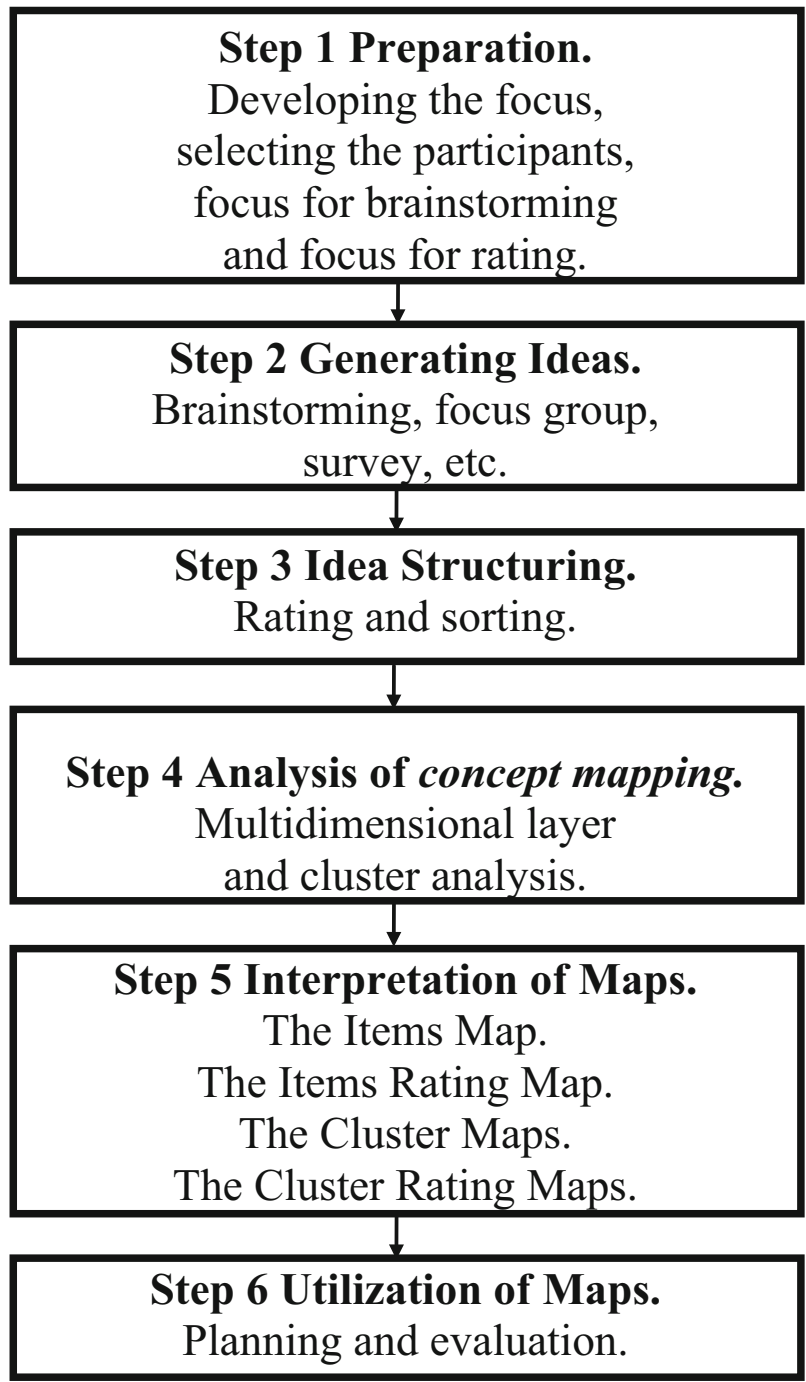

Fig. 1 Process of concept mapping. Adapted from Trochim (1989, p. 3)

professionals responsible for municipal management, each with a minimum of seven years of experience in a variety of the most important areas, chosen either by a random criterion, or that of professionalism.

In the present case, the statistical study was not carried out for actual use, but to identify instead which public services could be optimized. This decision was made to question professionals by combining both quantitative and qualitative data in order to follow the method of concept mapping (Trochim 1989).

The task agreed by the researchers was to make a list of innovations whereby information technology can be used to improve a service at the Town Council, or create a new one. 
The scale chosen for our research was a Likert-type scale from 1 to 5 . The question: How useful do you consider each separate item? ranged from: 1. Totally dispensable to 5. Extremely important.

The procedure was explained at length to those who would form a part of a brainstorming session to improve Public Administration services. Several cards were handed out to each participant to write a single idea per card, and his/her name was indicated on each one. Participants were also told that they should express their ideas clearly and concisely, without considering whether they would be put into effect or not. During this process, excessive amounts of information were not provided so as not to skew valid ideas or influence thought processes. In accordance with procedures described in previous studies (Bigné et al. 2002), a facilitator was chosen from the researchers in the prior preparation and idea-generation stages.

Brainstorming alternatives are suggested in the experiments by Nabitz et al. (2007), focusing on the object of the analysis, and by Simpson (1994), who worked remotely with a focus group and questionnaires. Other studies on concept mapping were also analyzed, such as Gil-Pechuán et al. (2014), Miranda-Gumucio et al. (2013), Rosas and Camphausen (2007), Rosas (2005), Toral et al. (2006), or Trochim and Linton (1986).

Next the participants were asked to group together the ideas that resulted from the brainstorming. The only limitations on this process were that not all the ideas should be listed in the same group, and to ensure that each idea was placed only in a single group.

When the stipulated time for generating ideas had finished, all the cards were collected, and any duplications and invalid cards were eliminated. In some cases, it was necessary to ask the author about an idea to better clarify exactly what he or she wished to express. This was why each card bore a name. As a result, an agreed list was prepared of 20 ideas or items (see Table 1).

Subsequently, a table was handed to each participant individually, in which he/ she rated each idea separately on the Likert Scale from 1 to 5. After completing this task, and cards had been collected, each participant was given as many cards as expressed ideas; that is, 20 cards to each participant.

Participants were asked to group the cards based on their similarity or proximity, without providing any indication whatsoever as to how many groups, whether they were large or small, should be formed. Once again they were told to work individually, and then each card was numbered.

The facilitator collected the cards from each participant and thanked them for their time. The researchers, now no longer with the study group, created the first table by adding up all the individual Likert score cards and dividing the sum by the number of participants to obtain a table with the total weighted scores per item. Subsequently, matrix tables per group of ideas and per individual, along binary and symmetric lines, were produced in which 0 indicated that two ideas were unrelated, and 1 indicate that they were related.

After preparing as many tables as participants, the second table was created, which was calculated by the sum of the squared and binary symmetrical matrices so that the diagonal corresponded to the number of participants (14). 
Table 1 Results of the first phase conducted with municipal management experts

1 Use of digital certification, with ID cards, for 2 General local government emergency services internal communication between administrations to speed up procedures

3 Teleworking opportunity via video conferencing

5 Paying municipal taxes online interconnected online to activate alarms (floods, fire, etc.)

4 See the file processing online status and document registration by citizens

6 Processing records online by citizens. Electronic signature

7 Express processing online for issuing use certificates, vending systems, using electronic signatures

9 Internal interdepartmental network with access to internal documental services and human resources

11 Direct implementation of information on the municipal website by internal staff, without intermediaries

13 Geographic Information System (GIS) for infrastructure maintenance, lighting services, gas, etc., with internal privileges, but restricted externally

15 Job training. Library of manuals and videos about how to do the tasks assigned

17 Online application for prior appointments for municipal operations

8 Citizenś online suggestion box

10 Personalized notification, emailed or texted, about the subscription list. Notification to citizens on subscribed matters

12 Geographic Information System (GIS) for administrative procedures with complete internal opportunity, but with restricted public access

14 Processing applications to use the public highway that involves several departments. Interdepartmental computer connection for increased efficiency

16 Service for group work. Shared diary keeping

18 Creating an internal municipal social network for interdepartmental communications

19 Free online access to webcams for tourism promotion and public safety

20 Using text messages at tourist attractions, e.g.,: "If you want to know the history of this monument, please text 5555"

\subsection{Analysis of the first phase results in relation to municipal management experts}

In the first place, an analysis was run which located each statement as a separate item on the point ratings map to obtain the dissimilarity array combined in twodimensional, multidimensional scaling. The points represented in each impact were spatially distributed so that the distances between pairs of points would have the maximum possible relationship with the similarity attributed by municipal management experts. Two similar impacts were represented by nearby points, and vice versa (Fernández 1991). Therefore, proximity to each other meant that they had been grouped with greater frequency.

To analyze the statements and definitions made from the individual concept mapping of the map clusters, we analyzed clusters (Anderberg 1973; Everitt 1980) by defining the 20 items as numerical economic variables, labeled by the 14 participants, where attempts were made to group items per set of ideas or clusters. Several tests were conducted with the method of linkage within groups from the closest neighbor, and also Ward's method to compare the results. 
As six of the fourteen participants grouped items into two groups, we first analyzed a scenario with two clusters, and obtained the results shown in Table 2, but later attempted with three clusters, as four of the fourteen subjects grouped items into three groups.

In this case, the items were classified into two groups according to their relationship. Here the objective was to use other cluster methods (not distance) to verify whether the self-same groups were formed, or were at least similar.

After analyzing all the results, six scenarios were found: two and three clusters with three methods: linking within groups, nearest neighbor method and the Ward method, the grouping obtained by the double cluster, as analyzed by the interlinking group method, was selected, and based on the criteria of matching the results their logical interpretation. Any other clustering group was ruled out.

By verifying the conglomeration record after applying the method, order and distance of junctions showed, for example, the following items: 4: Citizen querying the stage of file processing and document registration online, 6: Processing records online by citizens. Electronic signature and 7: Express online processing in issuing use certificates. Vending systems, using electronic signatures, indicated a distance of 0.000 , which was a perfect definition of the second cluster.

Given the null distance among items 4,6 , and 7 , graphically plotted on a single point, we felt that experts considered it to be the same concept, but expressed in various ways.

In order to end the final analysis of the method in this stage, we performed concept mapping by grouping the items into two weighted clusters, as shown in Fig. 2.

The number of each cluster $(1,2)$ appeared with its weighted value. It should be noted that on a 1-5 Likert scale, a cluster could have a maximum score of 5 .

The first cluster, Technologies to improve internal municipal management: labor management and processes, obtained a weighted score (the higher of the two resulting clusters) of 3.99 out of 5. It features items that relate to coordination of work between departments, teleworking, using an intranet for information sharing or including GIS, among others.

Table 2 Clusters from the first phase of the inter-linked group method

\begin{tabular}{|c|c|c|c|}
\hline \multicolumn{2}{|l|}{ CLUSTER 1} & \multicolumn{2}{|l|}{ CLUSTER 2} \\
\hline $\begin{array}{l}\text { 1: Digital } \\
\text { certification }\end{array}$ & 12: GIS processing & 4: Processing inquiry & 10: Subscription lists \\
\hline 2: Alarm system & 13: GIS services & 5: Paying taxes online & $\begin{array}{l}\text { 17: Online } \\
\text { appointments }\end{array}$ \\
\hline 3: Teleworking & $\begin{array}{l}\text { 14: Public highway } \\
\text { occupation }\end{array}$ & 6: Electronic signature & 19: Webcams \\
\hline $\begin{array}{l}\text { 9: Interdepartmental } \\
\text { net }\end{array}$ & 15: Training & $\begin{array}{l}\text { 7: Express online } \\
\text { processing }\end{array}$ & 20: Tourism texts \\
\hline \multirow{2}{*}{$\begin{array}{l}\text { 11: Municipal } \\
\text { website }\end{array}$} & 16: Shared diary keeping & 8: Suggestion box & \\
\hline & 18: Internal social net & & \\
\hline
\end{tabular}




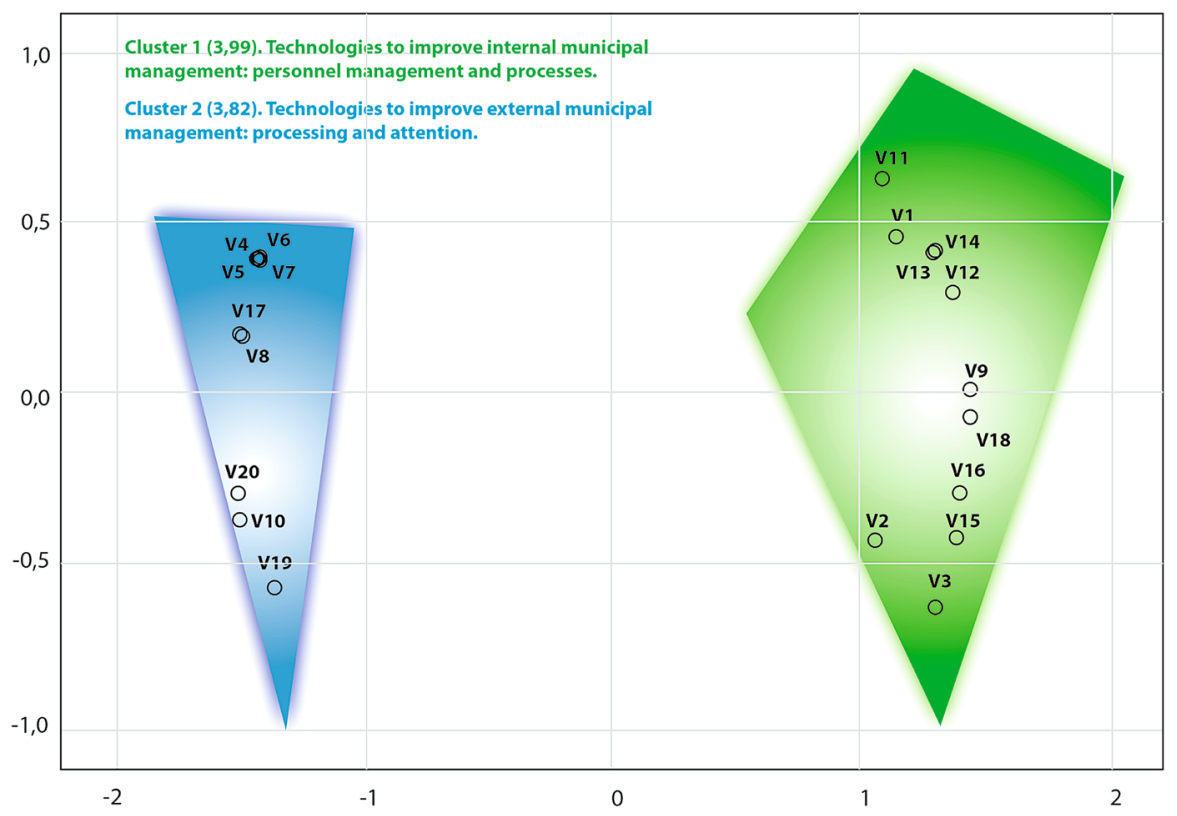

Fig. 2 Concept mapping applied to the opinions of municipal management experts

The second cluster, Technologies to improve external municipal management: processing and attention, had a weighted score of 3.82 out of 5. This cluster featured improvements related to the documentary streamlining of procedures to obtain environmental permits for procedures and to Responsible Declarations, in accordance with the Law 2/2006, of May 5, on preventing pollution and environmental quality, as well as to paying taxes online.

The ideas with the greatest weight assigned by the experts, according to the dissimilarity matrix (Trochim 1989), were as follows: 4: Consulting the processing of files and the registration of documents online by citizens and 9: Interdepartmental intranet, with access to internal documentary and personnel services, with a weighted score in both cases of 4.64 out of 5. It was noteworthy that the two most important improvement estimations belonged to one cluster or another, one from an internal and organizational point of view, and the other from an administrative point of view. This provides an overview of the most representative ideas in the participantś judgment and should, in the case of endeavoring to improve Public Administrations, be the priority line of any municipal strategic axis.

\section{Identifying technological needs in tourism according to business management experts}

In this case, we called 40 experts in business management from the tourist sector in May 2013 to perform the same methodology previously used with the municipal management experts, whose scope of activity coincided with the final objective. The 
objective was to compare the results of the same situation, considered from two points of view, in order to develop a collaborative research model, together with the current study on collaboration between public and private sectors in Spain (Torres and Pina 2001), and on the tourist sector in particular (Zapata and Hall 2012). The idea was to accomplish a PPP that would allow the public sector to benefit from the commercial dynamism that could increase finances, especially when budgets are currently restricted. It could enhance innovation and efficiency by introducing investors from the private sector, who could contribute with their own capital, skills, and experience (Menon and Manoj 2014). Forty business experts convened, and ranged from hotel managers to managers of sports facilities and tourist services.

The participants who would form part of the brainstorming session had the same procedure as that employed in the first phase explained to them. The aim was to improve Public Administration services from the demand perspective in order to be more competitive, which resulted in a list of 20 suggestions (see Table 3).

\subsection{Analysis of the second phase results of the expert opinions of business managers in the tourist sector}

Based on the weight of the items, variables, and the consolidated tables, and seeing that half of the forty entrepreneurs grouped items into three groups, we started from a classification into three clusters. Then we analyzed the data with four clusters, since fourteen of the forty subjects grouped items into four groups, although this result was finally discarded.

The symmetric distance matrix showed the distances between items according to the Euclidean distance squared, which indicated that the first cluster, in this case cluster B, was formed by the closest items (less distance between them) which are items: 9: Municipal input register online and 14: Access to information of procedures and regulations applicable when applying on the municipal website for licenses, with a distance of 0.786 , to which is added item 19: Online processing of municipal licenses or applications, at a distance of 0.840 item 9 and item 21: Online consultation of documental processing, a distance, in respect of item 9 of 0.974 . Thus we obtained the clusters shown in Table 4.

Data analysis indicates that identical clusters were obtained by linking both the within groups and Ward linkage methods. When analyzing by the nearest neighbor method, the results varied, but were still similar to cluster B, except in the case of two items (15 and 23) compared to the former cited methods, from which it was deduced that items were closely related.

By testing with four clusters, since 14 of the 40 subjects chose this option, a new fourth cluster was observed with only two generated items: 15: Storage of CVs accessible online to entrepreneurs in the tourist sector and 23: Online communication with entrepreneurs for all new offers and grants. However, we believed that they failed to show a distinctive identity. Therefore, the four clusters were rejected.

Having analyzed all the results, six scenarios (three and four clusters using Linking within groups, Nearest neighbor and Ward methods) were obtained on the basis of the criteria matching results and their logical interpretation. The three cluster group, obtained by the inter-linkage method, was chosen. 
Table 3 Results of the second phase by business management experts in the tourist sector

1 Municipal website accessible in different languages

3 Real-time online chat room for responding to 4 questions or doubts on complaints procedures

5 Online promotion of local tourist services (apartments, hotels, camping, catering)

7 Online real-time webcam road traffic information

9 Municipal online input register

11 Joint events diary accessible via municipal website

13 Mobile application for the hospitality/tourism in the town/city, with the most important tourist routes indicated

15 Storage of CVs accessible online to entrepreneurs in the tourist sector

17 Directory of local council e-mails to inform about doubts or suggestions

19 Online processing of municipal licenses or applications

21 Online documental processing inquiry

23 Online communication with entrepreneurs as regards all new offers and grants

25 QR Code on monuments, and marsh routes, etc., to explain the history of the monument or path specified
2 Online Wi-Fi access to municipal mapped points

4 Municipal centralized service for all local accommodation

6 Online webcam weather information accessible on the beach

8 Mobile application to indicate the locations of police, town/city council, duty chemist, health center, and other necessary public services

10 Texts communication with the town/city council, accompanied by images of anomalies, incidents (broken pavements, etc.), and emergencies

12 Potential tourism and catering client database for circulating information

14 Access to information of applicable procedures and regulations when applying on the municipal website for licenses

16 Platform on the internal online network with hotel and restaurant information to exploit synergies. Recommendations according to the service requested

18 Subdivision on the municipal website for each trade requested, organized by sector, with the possibility of hiring said services

20 Online directory of municipal departments, with the procedures performed by each one, and with tourist information points whenever possible

22 Application for appointments online with technical and municipal authorities

24 Municipal social network that focuses on tourism with opinion and information exchange to create synergies

To finalize the analysis in this second phase, we performed concept mapping by grouping items into three weighted clusters, i.e., by adding the value of the items weighted in each cluster, which were then divided by the number of items contained in the cluster. As a result, we obtained Fig. 3.

Cluster A was the least valued at 3.58, labeled Technology for online geoservices. 
Table 4 Clusters resulting from the second phase by the group inter-linkage method

\begin{tabular}{lll}
\hline CLUSTER A CLUSTER B CLUSTER C \\
\hline
\end{tabular}

1: Municipal Web accessible in multiple languages

2: Wi-fi online access to municipal mapped points

6: Online webcam weather information accessible on the beach

7: Online real-time webcam road traffic information

8: Mobile application to indicate the locations of police, town hall, duty chemist, health center, and other necessary public services

25: QR Code on monuments, and marsh routes, etc., to explain the history of the monument or path specified
3: Real-time online chat room for responding to questions or doubts on complaints procedures

9: Municipal input register online

10: SMS Communication with the town hall, accompanied by images, of anomalies, incidents (broken pavements, etc.), and emergencies

14: Access to information of procedures and regulations applicable when applying on the municipal website for licenses

\section{5: Storage of CVs accessible} online to entrepreneurs in the tourist sector

17: Directory of e-mail contacts of the municipal council for the communication of doubts or with suggestions

19: Online processing of municipal licenses or applications

20: Online directory of municipal departments, indicating those procedures performed by each of them. Where possible with tourist information points

21: Online consultation of documental processing

22: Application for appointments online with technical and municipal authorities

23: Online communication with entrepreneurs with respect to all new offers and grants
4: Municipal centralized service for all local accommodation

5: Online promotion of local tourist services (apartments, hotels, camping, catering)

11: Joint events diary accessible via municipal website

12: Potential tourism and catering client database for circulating information

13: Mobile application for the hospitality and tourism in the town, with the most important tourist routes indicated

16: Platform on the internal online network with hotel and restaurant information to exploit synergies.

Recommendations according to the service requested

18: Subdivision on the municipal website for each trade requested, organized by sector, with the possibility of hiring said services

24: Municipal social network focused on tourism with opinions and information exchange, in order to generate synergies 


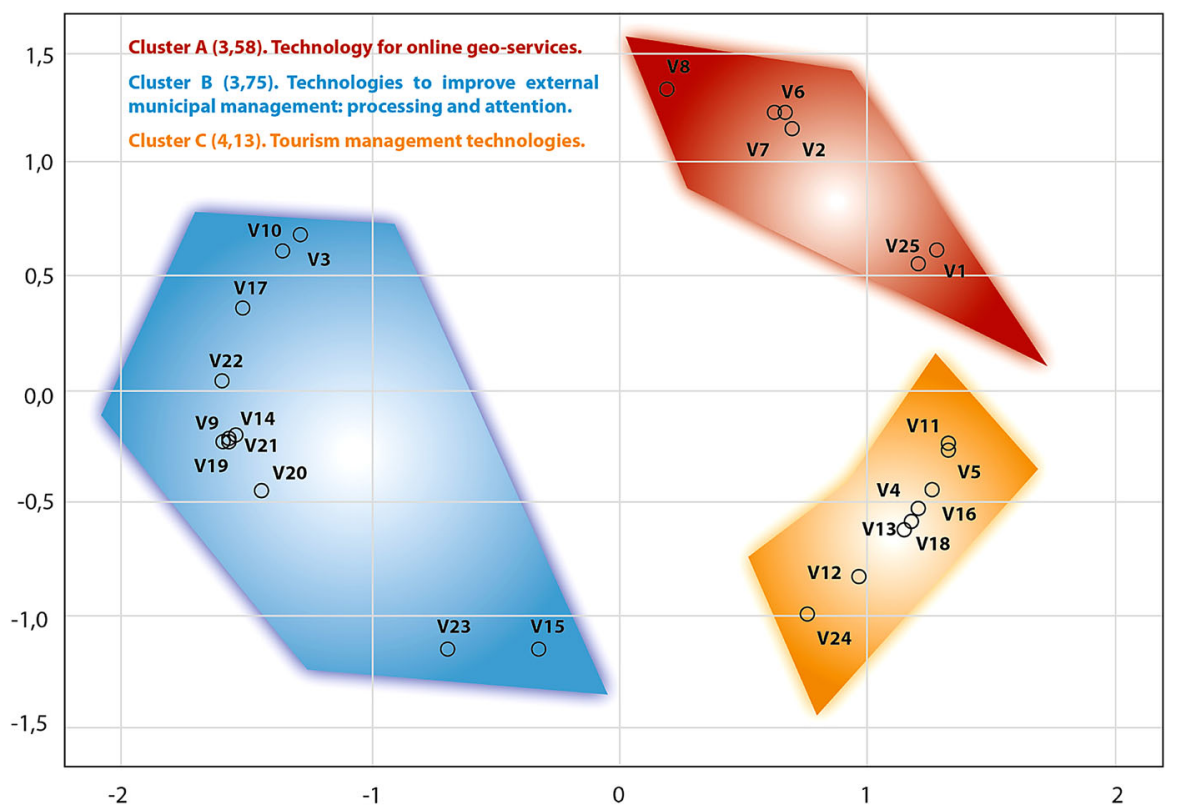

Fig. 3 Concept mapping applied to the opinions of the business management experts in the tourist sector

Cluster B reveals the most closely related items, with an average value of 3.75 . The name most repeated by most entrepreneurs was Technologies to improve external municipal management: processing and attention.

Cluster $\mathrm{C}$ had the highest weighted score, above 4.13, namely Tourism management technologies, a whole cluster dedicated to tourism. A bias could exist in seeking profitability, but it is undeniable that Public Administrations directly affect a city/towńs tourism development (Gil-Lafuente and Kyun-Oh 2012). There are some examples of tourism recommendations, and of coordinating existing resources, such as that of Marzo-Roselló et al. (2013).

The ideas with the most importance attached were as follows: 4: Municipal centralized service for all local accommodation, with a weighted score of $4.57 ; 5$ : Online promotion of local tourist services (apartments, hotels, camping, catering), with a weighted score of 4.5, both of which come from cluster C; and 1: Municipal web accessible in several languages with a weighted score of 4.5 , which belonged to cluster A.

It should be noted that the two most important ideas belonged to cluster $\mathrm{C}$ which, in turn, had the highest weighted score of the three resulting clusters. So it can be stated that entrepreneurs look to effectively promote their services, not in isolation, but rather through exploiting synergies, which could result from collaboration between tourism enterprises. Such collaboration is to be achieved through a coordinated agenda of events, which may well be enhanced by a municipal website which, despite addressing tourism, should be accessible in several languages. Emphasis was placed on the importance of the idea that foreign tourists may access 
a platform that responds to the specialized demand for tourism services, and justifies the importance of demand as defined in Porteŕs diamond (1990), which calls for using technology to support municipal care services.

\section{Proposal for a collaborative model between local government and tourism operators}

Following the application of the concept mapping method for cluster analysis, we were able to address not only a qualitative, but also a quantitative evaluation by seeking the opinions of experts. This allowed us to determine which technology services are demanded by both sectors: Public Administrations and tourist entrepreneurs.

The literature indicates that competitiveness is not generated by a single sector alone, rather by the complementarity between different local and private sector services (Nicholson and Orr 2016). Our contribution to this was to simultaneously conduct two agreed pilot schemes in parallel in a highly competitive municipality of the tourist sector.

As the two experiments demonstrated, the two clusters with the closest relationship were cluster 2 (municipal management experts) and B (business management experts in the tourist sector), both identified as Technologies to improve external municipal management: processing and attention. Table 5 shows that cluster B was slightly larger, with 11 items out of 25 possible ones, while cluster 2 had 9 items out of 20 possible ones. They also occupied the same two quadrants in conceptual mapping and had a similar cluster weight of 2 (3.82) and B (3.75).

In terms of content, we found that the objective for both parties was to improve the communication between local administrations and their client: the public. Both agreed on the objective of dealing with all paperwork over the Internet to speed up the processing of documentation on formal applications and issuing licenses because, for example, granting environmental licenses can currently take years.

Table 5 Summary of the resulting clusters

\begin{tabular}{ll}
\hline $\begin{array}{l}\text { Clusters of municipal management experts (20 } \\
\text { items) }\end{array}$ & $\begin{array}{l}\text { Clusters by in business management experts the } \\
\text { tourist sector (25 items) }\end{array}$ \\
\hline $\begin{array}{l}\text { 1.- Technologies to improve internal municipal } \\
\text { management: personnel management and } \\
\text { processes (3.99), } 11 \text { items }\end{array}$ & $\begin{array}{l}\text { A.- Technology for online geo-services, }(3,58), 6 \\
\text { items }\end{array}$ \\
$\begin{array}{l}\text { 2.- Technologies to improve external municipal } \\
\text { management: processing and attention. (3.82), } 9 \\
\text { items }\end{array}$ & $\begin{array}{l}\text { B.- Technologies to improve external municipal } \\
\text { management: processing and attention, (3.75), 11 } \\
\text { items } \\
\text { C.- Tourism management technologies, (4.13), 8 } \\
\text { items }\end{array}$ \\
\hline
\end{tabular}


Cluster C (Tourism management technologies) is entirely based on tourism, and is the most highly evaluated of them all (4.13). However, it is noteworthy that there is no connection with any of the clusters inside local government. Our only interpretation of this is that municipal management experts do not believe that the promotion and internal management of tourism businesses forms part of their competence.

Cluster 1 (Technologies to improve internal municipal management: personnel management and processes) is a compendium of the technological tools needed to successfully fulfill objectives. What is evident in this cluster is the need for an adequate geographical information system to facilitate administrators' work, which ranges from cadastral identification to possibly granting building permits, by simply clicking on an interactive map. A well-organized, internal interdepartmental network is also required to respond quickly and promptly to diverse and multiple registered inputs.

Finally, in cluster A (Technology online geo-services), similar items to some to those of the content in the following clusters were found: 1 (Technologies to improve internal municipal management: Personnel management and processes) and 2 (Technologies to improve external municipal management: processing and attention). This is because item 1 on the municipal website also appears in cluster 1 . Then there are item 11, and items 6 and 7 based on webcams, which appear as item 19 in cluster 2. Finally, items 8 and 25, based on text messages and QR codes, are also found in item 20 of cluster 2 . In this case, we consider this cluster to be the result of attaining clusters 1 and 2 as it did not function without the proper and prior infrastructure. This indicates that municipal services have a direct bearing on the tourism management in the municipality.

In order to develop competitive advantages, the first approach in Fig. 4 shows a collaboration model between the local government and entrepreneurs in the tourist sector, where all the influential agents are indicated. Figure 4 was produced according to Table 5 in order to bridge the gap created in the collaboration between the Public Administrations and the businesspeople from the tourist sector (PPP). The obtained results from the mapping concepts offered in Figs. 2 and 3 are represented in such a way that by analyzing what both agents demand, we can see what they coincide into propose a collaborative model.

Given the results obtained from the cluster analysis, found in studies on innovation strategies (Henao-Betancur et al. 2013), and specifically on business strategies in the tourist sector (Aziri and Nedelea 2013), a decision was made that the results obtained in Tables 1 and 3 should be re-analyzed and adapted to innovation via the Ansoff product market matrix, as shown in Table 6. Here we can see that the first quadrant is composed of the existing know-how, the second quadrant contains the ICT innovations proposed by business management experts, the third quadrant shows the ICT innovations proposed by municipal management experts, while the fourth and final quadrant consists of the matches found in the innovations proposed by both groups of experts.

The challenge was to now discern which agents should be involved, and to what extent, in each quadrant. For the second quadrant, they must necessarily result from a comprehensive collaboration between business and public Administration, with 


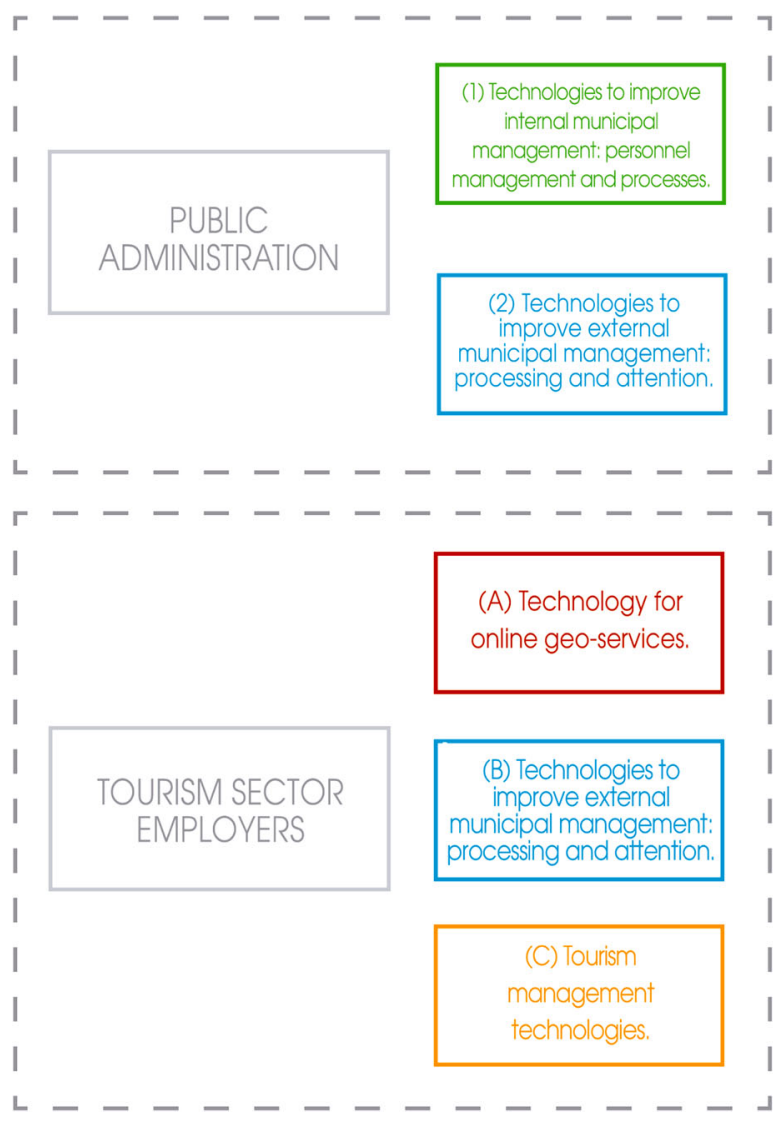

Fig. 4 First approach to the collaborative model

defined objectives and responsibilities, a joint budget reserve or contingency fund, and an implementation schedule. Reluctance to change appears as a major barrier to overcome, as far as improvements are concerned, in both public sector workers who offer innovative services and entrepreneurs who work for themselves with these new services. One of the challenges facing public administration is to encourage society to accept them.

The proposed innovations in the third quadrant need to begin with the local government's willingness, which must also enjoy a large enough majority to be able to carry out new initiatives in services. Secondly, there must be sufficient budget reserve and the implementation schedule must be realistic. Finally, as indicated in the second quadrant, the actual implementation of improvements must overcome the reluctance of government workers to change, and of society to accept them.

In the fourth quadrant, the proposed innovations are shown, which coincide in both parties, thus the circumstances described in the second and third quadrants must merge and, close collaboration between the government and business will be imperative. 
Table 6 Proposed ICT-based innovations of a collaborative tourist model

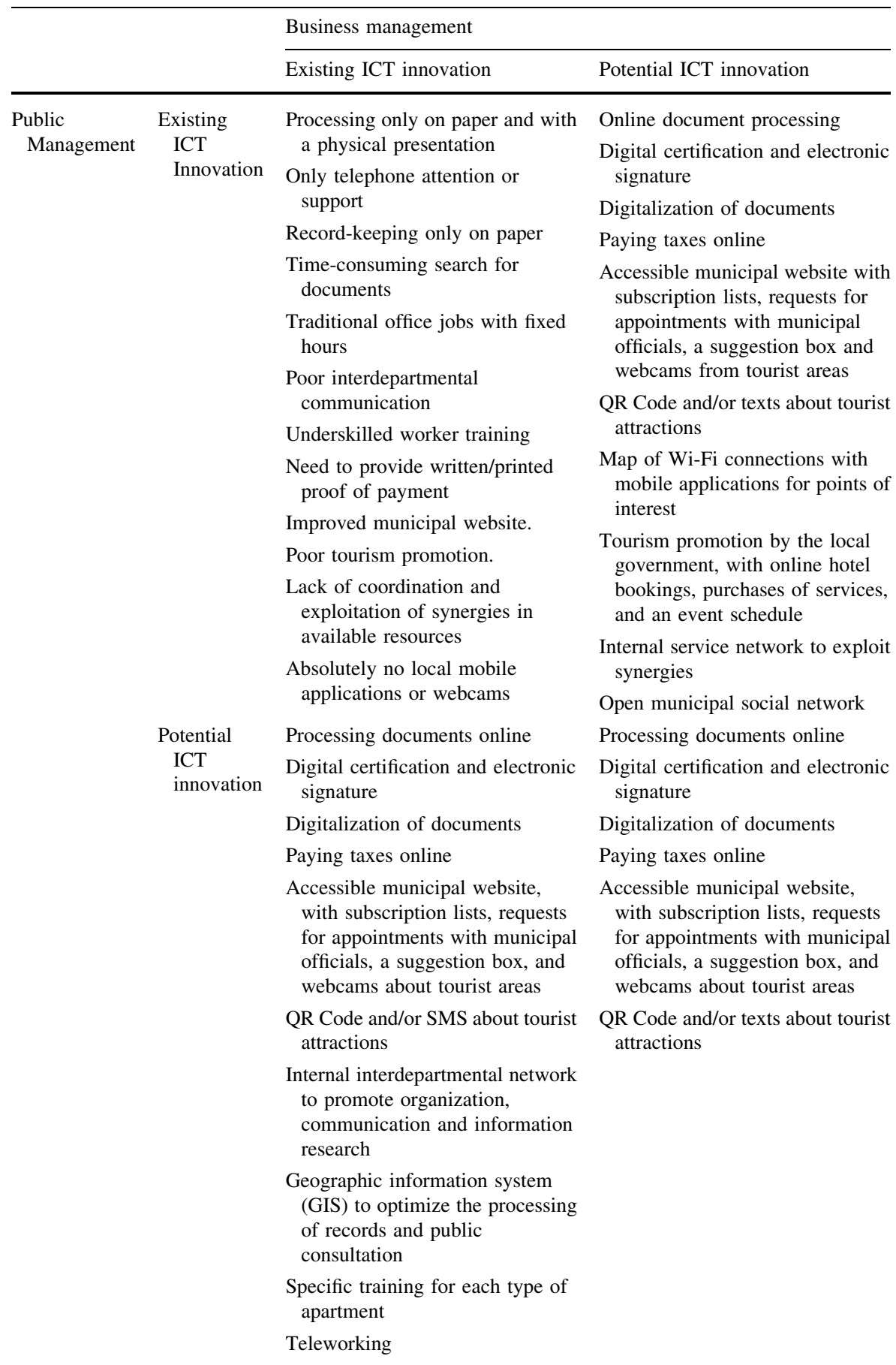


In each quadrant, all agents will be involved in a different way and to different extents based on the following four factors: speed and flexibility, understood as documentary diligence and promptness; profits made, referring to the economic profit from the private sector point of view, and social benefits that affect citizens positively from the public administrations perspective; the economic investment required to implement innovation; and finally, reluctance to change that can arise in both public sector workers and the general public, as shown in Table 7. These factors indicate the weighted estimation for each innovation that corresponds to the government, and to all entrepreneurs collectively in the tourist sector. This table offers the weighting obtained on historical statistical data taken from available analyses and reports from local government.

By analyzing the previous table, and in the order that innovations were proposed, we identified those innovations suggested by the tourism operator group that would speed up communication with the administration, and be beneficial for the private business sector. The values for these innovations ranged from 0.24 to 0.76 for the administration's case of tourism promotion where, following the same example, no significant difference $(0.41-0.59)$ in profits was observed. With regard to the economic investment required for the purposes of implementation, it would be split, but with the liońs share borne by the administration given the creation of an open municipal tourist social network, with $0.77-0.23$ in the most extreme case. Reluctance to change was widely distributed with maximum values ranging from 0.42 to 0.58 for introducing an internal network to exploit synergies.

The singular innovations proposed by the Public Administrations would have a notable effect by speeding up internal processes, where they obtained a marked advantage with values of up to $0.97-0.03$. Conversely, they would also require nearly all the available investment, as evidenced by the dichotomy of the ones and zeros in the table. However, profits would also fall mainly to Public Administrations, with special reference made to creating an internal interdepartmental network that would facilitate information searches, with values of $0.82-0.18$, and teleworking. Conversely, reluctance to change obtained the highest percentage, with values reaching $0.86-0.14$, for the implementation of a geographic information system. This highlights the strong inertia to overcome making changes in the internal processes of a large organization.

Finally, the innovations in which both parties coincide would entail the widespread speeding up of processing, with an evaluation of 0.5 for three of the six proposed innovations: online processing of files, digital certification and electronic signature, and paying taxes online. This stresses the need for improvement and ease of communication demanded by both parties. The profits to be obtained are also distributed between the two, which highlights the obvious discrepancy in investment, and this should show a return on investment for paying taxes online, the municipal website and QR codes. Regarding reluctance to change, the local government would also bear almost all the burden, with values from 0.82 to 0.18 for online processing of records.

Based on the above estimations, we conclude that the public administrations which, in most cases, incur most of the investment made for these innovations, and face the greatest reluctance to change to speed up, would be more efficient and, 


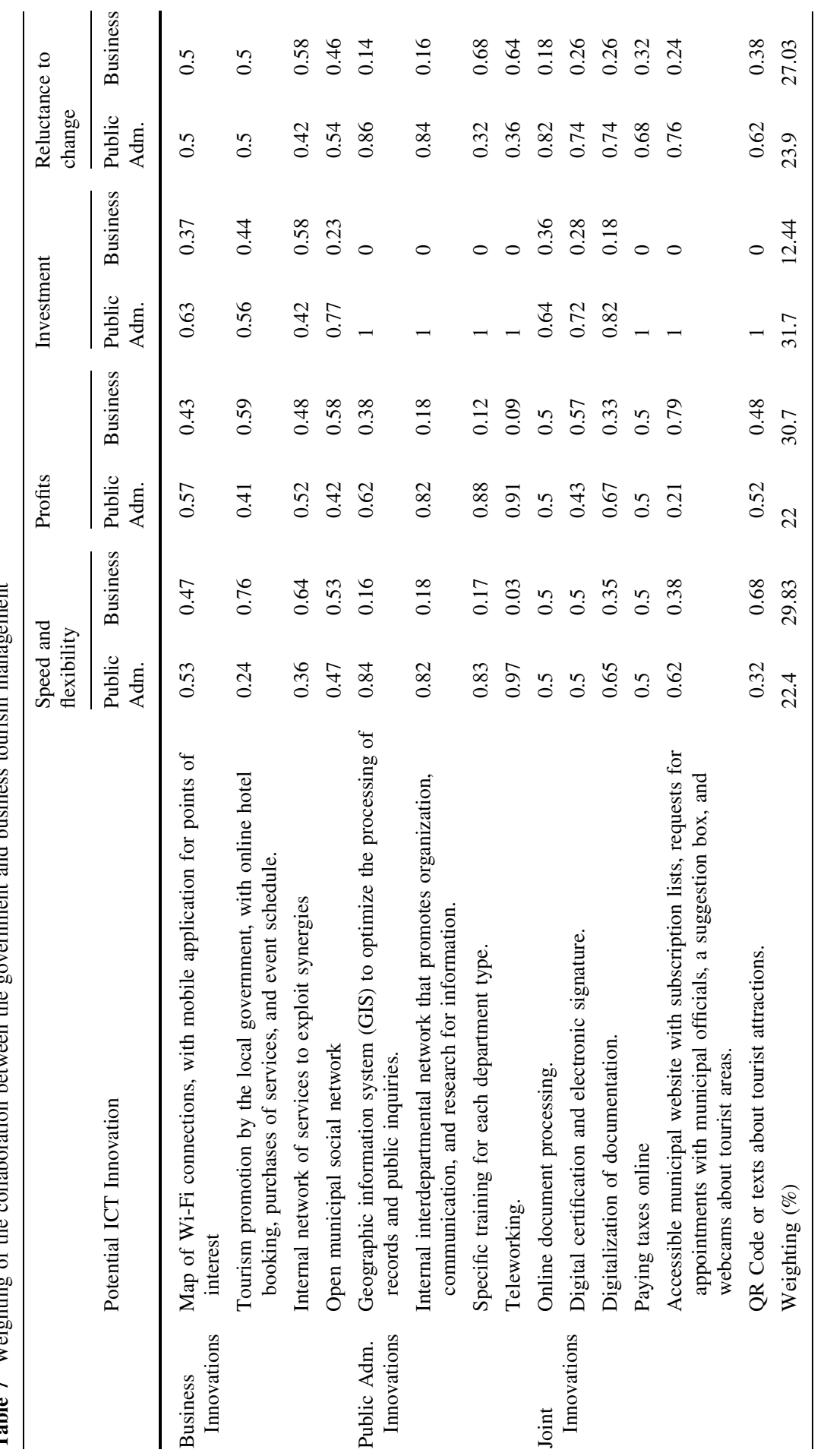




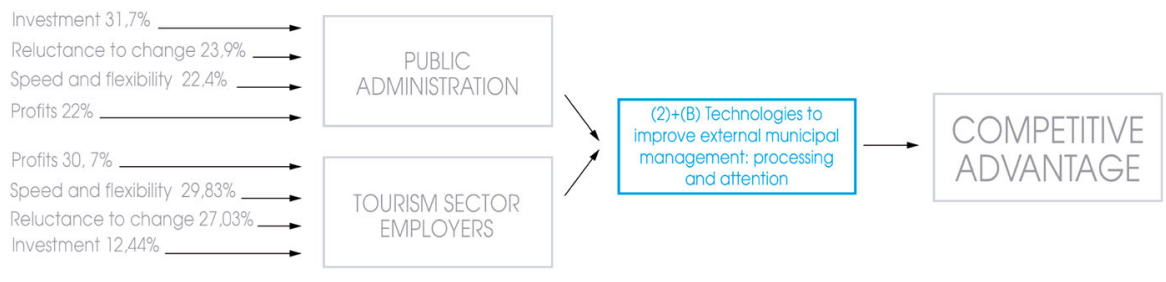

Fig. 5 Proposed collaborative model

consequently, create profits to be shared with the private sector of the tourist industry. Thus when analyzing the data in Table 7, we see that the weighting of the four factors for the public administration is as follows: Speed and flexibility $22.4 \%$, Profits $22 \%$, Investment $31.7 \%$, and Reluctance to change $23.9 \%$. The same figures for the private tourist sector are as follows: Speed and flexibility $29.83 \%$, Profits $30.7 \%$, Investment $12.44 \%$, and Reluctance to change $27.03 \%$.

Such is the justification for the collaborative model proposed in Fig. 5, in which both public administration, and the group of all the tourism entrepreneurs, should coordinate to fulfill the agreed innovations. These would consist of applying technology to improve external municipal management in order to optimize the exchange between them, by passing directly from the first to the fourth quadrant in Table 6 , in order to gain a competitive advantage, which will lead to a substantial improvement in communication between both parties.

Figure 5 establishes that the most influential factor in the Public Administrations is the need for investment to undertake the agreed innovations, with $31.7 \%$ followed by the potential reluctance to change to implement them $(23.9 \%)$. In contrast, we note that among all the tourism entrepreneurs, the most influential factor for undertaking innovations is the expected economic profits, with $30.7 \%$, followed by speeding up bureaucracy and fluent communication between both parties, with $29.83 \%$. That is, the business community is concerned with promoting tourism to make more profits, and efficiency in dealing with the administration for processing licenses and joint-problem solving. However, the Public Administrations require funding to modernize their filing systems and connectivity, and to train employees to adapt to change, where special emphasis is placed on overcoming the inertia of a large organization with a long-standing organizational methodology.

\section{Conclusions}

This research identifies the means by which, through close collaborative innovation between local government and tourism entrepreneurs (PPP), a competitive advantage may be achieved, along with collaborative innovation in services. For this purpose, we gauged the opinions of a group of municipal management experts with at least 10 years of experience in running various departments, and a considerable number of entrepreneurs whose activity is closely related to tourism and who thus share the same scenarios and have an in-depth knowledge as key 
stakeholders. This allows the fulfillment of the four critical success factors for tourism partnerships (Augustyn 2000) which include expert preparation, right underlying objectives, developmental structure, effective and efficient actions and the sustainable nature of the partnerships the selection of experts, setting specific objectives, and the developmental structure of the partnership. Resources were coordinated to avoid duplicating efforts and to provide an all-round service and, finally, effective and efficient actions of the partnership by fulfilling the set objectives by optimizing available resources.

In both brainstorming sessions, lists of proposed innovations were made in order to improve municipal services. An analysis was chosen, which combined both qualitative and quantitative insights because, as the two groups of experts coincide the same field, they could reflect a more complete reality than a merely quantitative approach (Trochim 1989). In view of the PPP concept, as we previously described, from the many studies available, the term tourism governance tends to be used as a synonym of cooperation, collaboration, or coordination, which evidently weakens its conceptual frame. Thus, we provided more representative definitions in order to limit the concept and, in turn, opted for a method that employs multivariate and multidimensional sample analyses. After completing the cluster analysis, the suggested innovations were divided into groups according to their proximity or similarity criterion. Thus two clusters were produced for the municipal management experts, and three clusters for the tourist sector-related businesses.

In order to propose a collaborative innovation model that bridges the gap between local government and businesspeople in the tourist sector, as Fig. 5 depicts, the results obtained by an Ansoff matrix were analyzed. Weighting was based on the following criteria: Flexibility and speed in procedures, Profits, Investment and the possible Reluctance to change which might arise, in such a way that a competitive advantage was confirmed which could be achieved through close collaboration between local government and entrepreneurs in the tourist sector. The local government should be committed to cooperate towards online record processing, paying taxes, and offer a better facility in arranging meetings with heads of the municipality and its departments; this would speed procedures up and would be more convenient for users, who can keep track of the progress made with their paperwork at their local government from home.

In short, it was established that the innovations that both tourism entrepreneurs and municipal management experts had prioritized corresponded to clusters 2 and B of Figs. 2 and 3, collectively called: Technologies for the improvement of external municipal management: processing and attention. This is because both parties have agreed on the need to substantially improve communication between the government and business. These two clusters, as indicated in Table 5, have a weighted score of 3.82 in cluster 2, composed of nine proposed innovations, and a weighted score of 3.75 in cluster B, composed of eleven proposed innovations, which, without being highly ranked, are nevertheless considered representative and contain a large number of innovations.

Regarding the situation shown in the first quadrant of Table 6, which indicates that the current application of ICT in Public Administrations is insufficient, Fig. 5 proposes setting up the innovations on which both parties agreed to, and as both 
agreed about the facts offered in Table 7, namely: the need for the widespread speeding up of administrative procedures; better communication between the local government and all tourism businesses; more profits for both. However, there would be repercussions, potential reluctance to change, and most of the investment would fall to the local government.

Thus following the mutually proposed innovations that emerge from the extensive experience of all those involved in this study, a new stage of fluency and flexibility in communication is expected, as well as simplification and transparency in procedures.

This will provide the municipalities that choose to follow the cited recommendations with a remarkably competitive advantage, and would confirm the aforementioned observations made by the Porter diamond (1990), namely the requisite of using technology to support municipal care services, and adherence to touristic recommendations, both coordinated with existing resources (MarzoRoselló et al. 2013).

The limitations of the research are inherent to the method used, where working with a limited number of experts can lead to obtaining partial data that do not contemplate the variety of perspectives that exist within the Spanish tourism sector. Evaluations should take into account that the data presented may be the result of biased opinions and correspond to a certain period of time. It should also be noted that the collaborative innovation model proposed has been developed from a particular case, although it is reasonable to assume that the model can be extrapolated to other contexts.

Open Access This article is distributed under the terms of the Creative Commons Attribution 4.0 International License (http://creativecommons.org/licenses/by/4.0/), which permits unrestricted use, distribution, and reproduction in any medium, provided you give appropriate credit to the original author(s) and the source, provide a link to the Creative Commons license, and indicate if changes were made.

\section{References}

Anderberg MR (1973) Cluster analysis for applications. Academic Press, New York

Augustyn K (2000) Performance of tourism partnerships: a focus on York. Tour Manag 2:341-351

Aziri B, Nedelea A (2013) Business strategies in tourism. Ecoforum 2(1):9

Baglieri D, Consoli R (2009) Collaborative innovation in tourism: managing virtual communities. TQM J 21(4):353-364

Barbero MI (2009) Métodos de elaboración de escalas. UNED, Madrid

Beaumont N, Dredge D (2010) Local tourism governance: a comparison of three network approaches. J Sustain Tourism 18(1):7-28

Beritelli P, Bieger T, Laesser C (2007) Destination governance: Using corporate governance theories as a foundation for effective destination management. J Travel Res 46:96-107

Bigné JE, Aldás J, Küster I, Vila N (2002) Estableciendo los determinantes de la fidelidad del cliente: Un estudio basado en técnicas cualitativas. Investigación y Mark 77:58-62

Bruntland GH (1987) Our common future. http://www.un-documents.net/our-common-future.pdf. Consulted in 2016

Buch EB, Cabaleiro R (2011) Hacia la determinación de la condición financiera de la administración publica local. Aplicación a los municipios de la comunidad autónoma de Galicia. Academia, Revista latinoamericana de administración, No. 47, pp. 43-60 
Burke JG, O'Campo P, Peak GL, Gielen AC, McDonnell KA, Trochim WM (2005) An introduction to concept mapping as a participatory public health research method. Qual Health Res 15(10):1392-1410

Bustelo C, García-Morales E (2008) Administración electrónica y gestión documental. Consideraciones a la luz de la ley para el acceso electrónico de los ciudadanos a los servicios públicos. El profesional de la información. Enero-febrero 17(1):106-111

Caffyn A, Jobbins G (2003) Governance capacity and stakeholder interactions in the development and management of coastal tourism: examples from Morocco and Tunisia. J Sustain Tourism 11(2):224-245

Carlisle S, Kunc M, Jones E, Tiffin S (2013) Supporting innovation for tourism development through multi-stakeholder approaches: experiences from Africa. Tour Manag 35:59-69

Clavero J, Codina M, Pérez A, Serrat-Brustenga M (2009) Estudio de caso de servicio de préstamo de libros electrónicos. El profesional de la información. Marzo-abril 18(2):237-241

Czernek K (2013) Determinants of cooperation in a tourist region. Ann Tourism Res 40:83-104

Dinica V (2009) Governance for sustainable tourism: a comparison of international and dutch visions. Journal of Sustainable Tourism. 17(5):583-603

Dredge D, Whitford M (2011) Event tourism governance and the public sphere. J Sustain Tourism 19(45):479-499

European Directive 2006/7/EC. Bathing Water. http://eur-lex.europa.eu/LexUriServ/LexUriServ.do?uri= OJ:L:2006:064:0037:0051:EN:PDF. Consulted in 2016

Everitt B (1980) Cluster analysis. New York, NY, Halsted Press, a Division of John Wiley and Sons

Fernández O (1991) El análisis de Cluster: Aplicación, interpretación y validación. Papers 37:65-76

Foundation for Environmental Quality of the European Union. http://www.blueflag.org/menu/awardedsites/2014/northern-hemisphere/spain-2/List/Beaches. Consulted in 2016

Freeman RE, McVea J (1984) A stakeholder approach to strategic management. Pitman, Boston

Gil-Lafuente AM, Kyun-Oh Y (2012) Incidencia de las inversiones de la administración pública sobre el desarrollo turístico de una ciudad. Revista Venezolana de Gestión Pública. Enero-Diciembre 3(3):81-109

Gil-Pechuán I, Conesa-García M, Navarro-García A (2014) Concept mapping to improve higher education. Innovation and Teaching Technologies. ISBN: 978-3-319-04824-6. pp. 61-73

Granovetter M (1985) Economic action and social structure: the problem of embeddedness. Am J Sociol 91(3):481

Greenwood J (1993) Business interest groups in tourism governance. Tourism Manag 14:335-348

Gulati R (1995) Social structure and alliance formation patterns: a longitudinal analysis. Adm Sci Q 40:619-653

Henao-Betancur PA, Echeverri-Farley OM, Zartha-Sossa JW (2013) Metodología web para la formulación e implementación de estrategias de innovación en empresas. Rev Gestión de las Personas y Tecnol 16:6

Hodge GA, Greve C (2017) On public-private partnership performance: a contemporary review. Public Works Manag Policy 22(1):55-78

Hultman J, Hall CM (2012) Tourism place-Making governance of locality in Sweden. Ann Tourism Res 39(2):547-570

Khattri N, Miles MB (1994) Cognitive mapping: a review and working guide. Center Policy Res, Sparkhill

Klodiana G, Dorina K, Engjellushe Z (2012) The role of local government in sustainable development. AUDOE. 8(2):139-155

León JA, Zapico F (2003) Usos prácticos sobre la política electrónica en los servicios públicos: el caso de Extremadura. El profesional de la información. Mayo-junio 12(3):232-236

Marinao E, Chasco C (2012) Trust in tourist destinations. the role of local inhabitants and institutions. Academia, Revista latinoamericana de administración 51:27-47

Marzo-Roselló R, Peris-Pérez P, Ferris-Oñate, Sánchez-Lacuesta J, Matínez-Gómez L, Olaso-Melis J, Garcés-Pérez L, Primo-Capella VJ (2013) La experiencia turística en la ciudad de Valencia. Rev de Biomec 59:63-66

Menon S, Manoj E (2014) Public private partnerships in tourism- a case study of Kerala Travel Mart. Afr J Hosp Tour Leisure 3(2):1-7

Miranda-Gumucio L, Gil-Pechuán I, Palacios-Marqués D (2013) An exploratory study of the determinants of switching and loyalty in prepaid cell phone users. An application of concept mapping. Serv Bus 7(4):603-622 
Miret-Pastor L, Segarra-Oña MV (2011) Estudio del clúster turístico de Benidorm a través de indicadores de aglomeración y especialización. Renovación de destinos turísticos consolidados, pp 69-86

Miret-Pastor L, Segarra-Oña MV, Hervás-Oliver JL (2009) Un análisis sobre la concentración espacial en el turismo valenciano. Congreso de la Asociación Española de Ciencia Regional. XXXV Reunión de estudios regionales, Valencia

Moscardo G (2011) Exploring social representations of tourism planning: issues for governance. J Sustain Tour 19(4-5):423-436

Muñoz-Cañavate A, Chaín Navarro C (2004) La administración local española en internet: estudio cuantitativo de la evolución de los sistemas de información web de los ayuntamientos (1997-2002). Ciencias de la Inf 35(1):43-55

Nabitz U, Severens P, Brink WVD, Jansen P (2007) Improving the EFQM model: an empirical study on model development and theory building using concept mapping. Total Qual Manag 12(1):69-81

National and Integral Tourism Plan (2012-2015) http://www.minetur.gob.es/turismo/es-ES/PNIT/ Documents/Plan\%20Nacional\%20e\%20Integral\%20de\%20Turismo\%20(PNIT)\%202012-2015.pdf. Consulted in 2016

Nicholson J, Orr K (2016) Local government partnership working: a space odyssey. Or, journeys through the dilemmas of public and private sector boundary-spanning actors. Policy Politics 44(2):269-287

Nordin S, Svensson B (2007) Innovative destination governance: the Swedish ski resort of Åre. Entrepr Innov 8(1):53-66

Nunkoo R (2015) Tourism development and trust in local government. Tour Manag 46:623-634

Pechlaner H, Tschurtschenthaler P (2003) Tourism policy, tourism organisations and change management in Alpine regions and destinations: a european perspective. Curr Issues Tour 6(6):508-539

Pfeffer J, Salancik G (1978) The external control of organizations: a resource-dependence perspective. Harper and Row, New York

Porter ME (1990) The competitive advantage of nations. Harv Bus Rev 68(2):73-93

Prahalad CK, Hamel G (1990) The core competence of the corporation. Harv Bus Rev 68(3):79-91

Queiroz F, Rastrollo-Horrillo MA (2015) State of art in tourist destination governance. Tour Manag Stud 11(2):47-55. doi:10.18089/tms.2015.11206

Rodríguez MP, López AM, Ortiz D (2010) Implementing the balanced scorecard in public sector agencies: An experience in municipal sport services. Acad Rev latinoam de adm 45:116-139

Rooter report (2010) La innovación en servicios en España. www.rooter.es. Consulted in 2016

Rosas SR (2005) Concept mapping as a technique for program theory development: an illustration using family support programs. Am J Eval 26(3):389-401

Rosas SR, Camphausen LC (2007) The use of concept mapping for scale development and validation in evaluation. Eval Progr Plann 30:125-135

Santos M, Ferreira AM, Costa C (2014) Influential factors in the competitiveness of mature tourism destinations. Tour Manag Stud 10(1):73-81

Selin S, Chavez D (1994) Characteristics of successful tourism partnerships: a multiple case study design. J Park Recreat Adm 12(2):51-61

Selin S, Chavez D (1995) Developing an evolutionary tourism partnership model. Ann Tour Res 22(4):844-856

Simpson B (1994) How do women scientists perceive their own career development? Int J Career Manag 6(1):19-27

Soler-López MC (2013) Calidad y Rendimiento de Sitios Web de e-Government. Aplicación a la Administración Local. Doctoral thesis. Murcia University

Spanish Tourism Plan Horizon (2020) pp. 24 and 43. http://static.hosteltur.com/web/uploads/2011/10/ Plan_de_Turismo_Espaol_Horizonte_2020.pdf. Consulted in 2016

Toral SL, Barrero F, Martínez MR, Gallardo S, Cortés FJ (2006) Determinación de las variables de diseño en el desarrollo de una herramienta de e-learning. Pixel-Bit, Rev de medios y edu 27:99-113

Torres L, Pina V (2001) Public-private partnership and private finance initiatives in the EU and Spanish local governments. Eur Account Rev 10:601-619

Trochim WMK (1989) An introduction to concept mapping for planning and evaluation. Eval Progr Plann 12(1):1-16

Trochim WMK, Linton R (1986) Conceptualization for planning and evaluation. Eval Progr Plann 9(4):289-308

United Nations World Tourism Organization (2005) Making tourism more sustainable. A guide for policy makers, UNEP and UNWTO, pp 11-12. http://sdt.unwto.org/content/about-us-5 
United Nations World Tourism Organization (2015) UNWTO tourism highlights, p 6. http://www.eunwto.org/doi/pdf/10.18111/9789284416899

Velasco GM (2007) Gestión de destinos: ¿Gobernabilidad del turismo o gobernanza del destino?. Ministerio de educación y ciencia de España. Plan nacional de I + D + I (2004-2007)

Wang Y (2008) Collaborative destination marketing: understanding the dynamic process. J Travel Res 47(2):151-166

Wang Y, Fesenmaier RD (2007) Collaborative destination marketing: a case study of Elkhart county, Indiana. Tour Manag 28:863-875

Wang C, Honggang X (2014) The role of local government and the private sector in China's tourism industry. Tour Manag 45:95-105

Williamson OE (1975) Markets and hierarchies: analysis and antitrust implications. The Free Press, New York

Wood DJ, Gray B (1991) Towards a comprehensive theory of collaboration. J Appl Behav Sci 27:139-162

World Travel \& Tourism Council (2016) Economic Impact 2016 Spain, p 3. http://www.wttc.org/-/media/ files/reports/economic\%20impact\%20research/countries\%202016/spain2016.pdf. Consulted in 2016

Zapata MJ, Hall CM (2012) Public-private collaboration in the tourist sector: balancing legitimacy and effectiveness in local tourism partnerships. The Spanish case. J Policy Res Tour Leisure Events 4(1):61-83 